\title{
Determination of Parallel Market Exchange Rate Premium
}

\author{
Oluremi Ogun \\ Department of Economics, University of Ibadan, Ibadan, Nigeria \\ Email: r_ogun@yahoo.com
}

Received 24 January 2015; accepted 11 February 2015; published 15 February 2015

Copyright (C) 2015 by author and Scientific Research Publishing Inc.

This work is licensed under the Creative Commons Attribution International License (CC BY). http://creativecommons.org/licenses/by/4.0/

(c) (;) Dpen Access

\begin{abstract}
A model of the determination of parallel market exchange rate premium in liberalized economies is presented. Clear distinction is made between fundamental and nominal determinants with economic justification(s) given for every variable. Likely data problems that may arise during implementation are discussed and suggestions on circumventing are made.
\end{abstract}

\section{Keywords}

Foreign Exchange Market, Parallel Market Exchange Rate Premium, Short Run, Long Run

\section{Introduction}

Considerable research attention was devoted to the issue of parallel market exchange rate premium (PMP) in the 1980s through to the late 1990s in the wake of the widespread adoption of liberalisation policies in developing countries. The list was indeed lengthy and included Nigeria [1], Brazil [2], Ghana [3], Sub-Saharan Africa [4] and Tanzania, Sudan and Turkey [5], Bolivia [6]. Post 2000s' investigations included some 49 countries in panel analysis [7] and selected developing economies [8]. The relative lull in related research activities in recent time would appear to be fallout of the perceived reduced importance imposed by the automatic check on the premium under the new policy dispensation. However, the recent steep and continuous fall in crude oil export price appeared to be generating the kind of market reactions giving birth to high level volatility in the foreign exchange market. ${ }^{1}$ Hence, research attention may again shift in the direction of the premium. ${ }^{2}$

In terms of economic significance, the premium is often associated with domestic currency overvaluation that

\footnotetext{
${ }^{1}$ The foreign exchange market is a formal (autonomous) market for the determination of foreign exchange rates through the interaction of market forces.

${ }^{2} \mathrm{~A}$ definition of the premium is in terms of the percentage excess of the parallel market rate over the official (and lately, the autonomous market) rate (see e.g. [2]).
} 
penalizes growth through a contraction of the tradable goods sector. Easterly and Levine [9] associated about half a percentage point in the annual growth of GDP with a 10\% exchange rate premium. In addition, depreciation of the related parallel rate insulates international reserves from capital outflows [6]; depreciation of the premium worsens balance of trade producing an accumulation of private net foreign assets through the parallel current account balance [5] and contributes significantly to inflation. Further, a sustained premium growth could reduce export revenue from official channels as the authorities compress imports to prevent reserve losses [5]. Thus, a study of the determination of the premium could be rewarding in terms of yielding insights into some important dimensions of the growth process.

This paper aims at providing a framework for analyzing the determination of the premium under a liberalized economic setting. In the process of achieving this aim, a clear distinction was made between short and long run determinants. The paper is organized as follows. Following this introduction is the section which provides a review of related theories and is succeeded by one on model specification. The section after dealt briefly with the issues of anticipated data problems while the final section provided a concluding remark.

\section{Theories of Parallel Market Exchange Rate Premium}

PMP has commonly been analyzed under two frameworks: the real trade models (RTMs) and the portfolio-balance (PB).

RTMs are age-long with contributors including [10]-[12]. They are usually partial-equilibrium models focusing solely on the developments in the parallel market without any input from the interactions in the wider economy. There are two propelling forces under this framework: 1) trade restrictions giving birth to illegal activities such as smuggling of exports and imports; and 2) scarcity of foreign exchange, tax avoidance and/or the need to avoid the official channel of sourcing foreign exchange to finance trade all of which combine to engender export under invoicing, import over invoicing and diversion of officially allocated foreign exchange. Generally, under this framework, smuggled imports represent the only source of flow demand while all the other illegal activities identified constitute the flow supply.

Agenor [4] identified the limitation of the framework which comes in two folds. First, under the models, the only reason to deal in foreign currency is to buy imported goods, thus assuming away the portfolio motive which has been identified as a crucial factor in the analysis of the demand for foreign currency. Second, the models even though provide a useful analysis of the long run determinants of the premium, contain no mechanism that satisfactorily explains the short run behavior of the premium which is taken as given by most exporters and importers in the models. However, there appears to be subtle short run gains' motive in the diversion of officially allocated foreign exchange.

The PB theory which has in recent times been associated with currency substitution motive appears to be particularly suitable in explaining PMP growth in high inflation economies and countries where considerable uncertainty over economic policies prevails. This class of models helps to explain the behavior of private agents in developing countries in using foreign exchange as a hedge against the depreciation of the domestic currency when a massive or major devaluation program is envisaged (e.g. a period of switch from fixed to flexible exchange rate regime).

Commonly referred to as stock-flow models and associated mostly with Dornbusch et al. [2], other varieties popularly referenced in the literature include [13]-[15]. Typically, the supply of foreign currency in the market is represented by the product of existing stock of foreign currency and the ruling exchange rate in the market while the demand is often taken as proportional to national wealth defined in terms of the sum of assets in domestic currency and the domestic currency equivalent of total foreign currency supplied to the market. This setting allows factors such as interest rate differentials between domestic and foreign countries and rate of depreciation of the domestic currency to play crucial roles in influencing demand for foreign currency.

By combining both nominal and real factors under an assumption of perfect foresight, the PB class of models provides considerable insight into the short and long run behavior of parallel market exchange rates. However, an oversight of some salient behavior of the policy authorities and factors associated with the structure of the economy both of which have important implications for the short and long run models of the premium appears to be characteristic of both the RTMs and PB even as a combined framework. This paper seeks to fill this gap.

A third framework focuses on monetary factors. In particular, monetary financing of fiscal deficits generates important implications for pricing developments in the parallel exchange rate market. For example, financing 
deficits through money creation raises the price level and also affects the real interest rate both of which in the absence of appropriate stabilization measures, influences the parallel market rate and by extension, the associated premium [see e.g. [16]]. ${ }^{3}$

Table 1 below presents taxonomy of the relevant factors affecting the premium in accordance with the pattern of their effects.

\section{The Model}

PMP has its short run and long run dynamics. The general expression of the PMP model would take the form:

$$
P M P=\alpha_{i}+\delta_{i} \text { Fund }+\gamma_{i} S D+\varepsilon
$$

where PMP is parallel market exchange rate premium, Fund is a vector of fundamentals, SD is a vector of short run determinants, $\alpha_{i}, \delta_{i}$ and $\gamma_{i}$ are parameters relating to the ith variable and $\varepsilon$ is random error.

The only credible fundamental from the RTMs is the need to trade which can simply be proxy by the degree of openness. Openness should have a negative effect on PMP because exports should grow faster than imports in the long run.

From the structure of the economy come three factors. The first is income or gross domestic product (Y), serving as proxy for productivity growth or technological change which should be faster in the tradable goods sector. A priori, it should exert a negative influence on PMP. The second are terms of trade (TOT) which should exert a negative influence on PMP since prices of exports should rise higher than those of imports in the long run. The third are foreign reserves (FR), which should ultimately influence PMP positively. There are at least three channels through which FR could influence PMP. One, through its influence on monetary and fiscal policies; two, through an expectations or prosperity fuelled demand for the domestic currency and three, through an influence on policy in favour of a more liberalized personal and business travel allowances as well as foreign remittances. Whereas the third channel should produce unambiguously, declines in the premium, the effect of the first two channels would be procyclical. On balance, however, foreign reserves should grow with sustained

Table 1. Factors affecting the premium.

\begin{tabular}{|c|c|c|c|}
\hline Factor & Effect & & Pattern of Effect \\
\hline Increase (decrease) in existing stock of dollars & \multicolumn{2}{|l|}{ Increase (decrease) } & Jump \\
\hline $\begin{array}{l}\text { Increase (decrease) in nominal interest rate } \\
\text { differential (adjusted) for official depreciation }\end{array}$ & $"$ & $"$ & $"$ \\
\hline Increase (decrease) in stock of domestic assets & \multicolumn{2}{|l|}{ Decrease (increase) } & " \\
\hline Increase (decrease) in commodity export taxes & \multicolumn{2}{|l|}{ Increase (decrease) } & " \\
\hline Increase (decrease) in export documentation & $"$ & $"$ & " \\
\hline Increase (decrease) in import controls (tariff) & $"$ & $"$ & " \\
\hline Increase (decrease) in tourist allowances & \multicolumn{2}{|l|}{ Decrease (increase) } & " \\
\hline Expectation of future maxi devaluation/revaluation & \multicolumn{2}{|l|}{ Increase (decrease) } & " \\
\hline Actual devaluation & \multicolumn{2}{|l|}{ Decrease } & Unchanged \\
\hline Seasonal factors & \multicolumn{2}{|l|}{ Increase/decrease } & Movement \\
\hline Expansionary monetary policy/budget deficit & \multicolumn{2}{|l|}{ Increase } & Jump \\
\hline Appreciation of real exchange rate & \multicolumn{2}{|l|}{ Increase } & Movement \\
\hline Terms of trade improvement & \multicolumn{2}{|l|}{ Decrease } & Jump \\
\hline Increase in capital flight & \multicolumn{2}{|l|}{ Increase } & " \\
\hline Increase in aid & \multicolumn{2}{|l|}{ Increase/decrease } & " \\
\hline
\end{tabular}

Sources: compiled from [2] [5] [17]-[19].

${ }^{3}$ The parallel market rate is the exchange rate determined by market forces in an informal market different from the formal autonomous market; under the current policy dispensation, it is often equated with the rate determined through the operations of bureaus de change. 
economic growth, hence the overall positive effect. It thus represents the long run wealth effect. ${ }^{4}$

Two fundamentals emerge from the policy circle. The first is government expenditure $(G)$ which, other things given, should grow overtime thereby providing the added impetus for growing demand in the parallel exchange rate market. It should exert an appreciating influence on PMP. The second is the narrow money supply (M) whose qualification is its exogenous nature.

Domestic inflation should exert an appreciating influence on PMP. The close relationship between money supply (M) and domestic inflation $(\pi)$ (sustained inflation being a monetary phenomenon) suggests "same effect" in terms of horizon; it is indeed delicately so. $\mathrm{M}$ in the form of surfeit of liquidity could render foreign currency holding an attractive portfolio choice, hence the appreciating influence on PMP. It enters as a fundamental because of the exogenous nature of narrow money. On the other hand, inflation would cause the demand for imports to rise, hence the appreciating tendency on PMP. In this sense, it may capture the short run effect of money supply. Ordinarily, in the long run, price level should be stable as there would tend to be a convergence of actual and expected inflation. However, if narrow money could change in the long run, price level could too. The differences in the channels of effect of money supply and domestic inflation become the sole criterion for admitting domestic inflation into the league of fundamentals.

The short run determinants include expected inflation $\left(\pi^{e}\right)$, real exchange rate misalignment (RERM), trade tariffs (T), seasonal factors (SF), capital flight (CF), real interest rate differentials (RIRD), bank deposits (BD) and corrupt practices (C).

Following the discussion on the effect of domestic inflation, expected inflation should exert an appreciating influence on PMP in the short run. RERM being an indication of relative price distortion should have a positive impact on PMP. ${ }^{5}$ Trade tariff (T) should have a positive effect on PMP in a manner somewhat similar to the effect of domestic inflation but it is strictly a level effect. Seasonal Factors (SF) should on balance exert a positive influence on PMP. It is a short run variable because in the long run, the various tourism promotion policies/ strategies should work to equate outflows with inflows. In any case, the effect of seasonal factors usually wears off after the relevant season. Capital flight (CF) should have a positive influence on PMP partly deriving its propelling force from real exchange rate misalignment. Real interest rate differential being a measure of relative profitability should negatively influence PMP. Bank deposits (M2 minus Currency) should have an appreciating influence on PMP. This would also reflect the effect of treasury deposits.

Corruption (C) [seen in terms of "round tripping" practices of banks and placement of treasury deposits in banks] enters into this model as a short run determinant exerting an appreciating influence on PMP. ${ }^{6}$

The complete model thus appears as:

$$
\begin{aligned}
P M P= & f\left(Y, \text { TOT, G, OPEN, FR, M, } \pi, \pi^{e}, \text { RERM, T, S, CF, RIRD, BD, C }\right) \\
& (-)(-)(+)(-)(-)(+)(+)(+)(+)(+)(+)(+)(-)(+)(+)
\end{aligned}
$$

All variables and the respective partials underneath are as defined and discussed earlier.

\section{Data Issues}

Some of the variables in the model may present serious challenges in terms of data. For example, some seasonal factors do not follow regular pattern of occurrence: pilgrimages to Jerusalem and Mecca do not occur in any one fixed month; so also are tourist attractions say, carnivals, organized in different cities/countries. As a result, it may be impracticable to use dummy variables to capture the effect of such seasonal events. The use of monthly data could address this problem as such data would reflect the seasonal changes in the demand and supply of foreign exchange. However, the fact that data on most of the other macro variables in the study are available only as annual or at the most disaggregated, quarterly, may invite the use of interpolation technique to generate

\footnotetext{
${ }^{4} \mathrm{~A}$ highly volatile factor-oil price-would affect the rates in both the autonomous market and the parallel market in the same direction hence leaving the premium relatively unchanged. In the long run, its effect would be reflected in changes in the stock of foreign reserves. As a result, the case for entering it as an independent explanatory variable is very weak.

${ }^{5}$ Theoretically, RERM which represents persistent deviation of real exchange rate (RER) from its long-term trend is usually taken to be a long run variable. It is submitted here that this view would hold only in the case of economies under economic regulation where prices are usually held at levels different from their equilibria. For a liberalized policy economy, frequent policy adjustments are usually occasioned by disequilibrating forces, hence prices tend to remain at or close to their steady state values, that is, stable and reasonably well aligned in the long run.

${ }^{6}$ In a situation where corruption is found to be intractable or generally accepted as a way of life, it would certainly constitute a fundamental.
} 
the monthly series. Finally, in order to avoid the likelihood of multicollinearity from the presence of both inflation and its expected version in the model, it is advised to generate the expected inflation from a rational expectations perspective, that is, as the fitted series in a short run specification of the determinants of inflation.

\section{Conclusion}

This paper had been concerned with the determinants of parallel market exchange rate premium, albeit at the theoretical level. A clear distinction was made between fundamentals and nominal determinants thus permitting the introduction of some new arguments into the function while also facilitating status' re-specification of some existing/known determinants. Some recommendations on the appropriate data to use in analysis were made.

\section{References}

[1] Azam, J.P. (1991) Cross-Border Trade between Nigeria and Niger: The Parallel Market for the Naira. In: Roemer, M. and Jones, C., Eds., Markets in Developing Countries: Parallel, Fragemented and Black. International Centre for Economic Growth, San Francisco, 47-61.

[2] Dornbusch, R., Dantas, D.V., Pechman, C., Rocha, R.R. and Simoes, S. (1983) The Black Market for Dollars in Brazil. The Quarterly Journal of Economics, 98, 25-40. http://dx.doi.org/10.2307/1885565

[3] Pinto, B. (1986) Fiscal Deficits, Inflation and Parallel Exchange Markets in Ghana: Monetarism in the Tropics? Discussion Paper 56, Country Policy Department, The World Bank, Washington DC.

[4] Agenor, P-R. (1992) Parallel Currency Markets in Developing Countries: Theory, Evidence and Policy Implications. Essays in International Finance No. 188, Princeton University, Princeton.

[5] Kiguel, M. and O’Connell, S.A. (1995) Parallel Market Exchange Rates in Developing Countries. World Bank Research Observer, 10, 21-52. http://dx.doi.org/10.1093/wbro/10.1.21

[6] Kharas, H. and Pinto, B. (1989) Exchange Rate Rules, Black Market Premia and Fiscal Deficits: The Bolivian Hyperinflation. Review of Economic Studies, 56, 435-447. http://dx.doi.org/10.2307/2297557

[7] Bahmani-Oskooee, M., Miteza, I. and Nasir, A.B.M. (2002) The Long-Run Relations between Black Market and Official Exchange Rates: Evidence from Panel Cointegration. Economic Letters, 76, 379-404. http://dx.doi.org/10.1016/S0165-1765(02)00081-2

[8] Acharyya, R. (2001) Exchange Rate Policy and Black Market Premium on Foreign Exchange: Theory and Evidence. Economic and Political Weekly, 36, 1984-1990.

[9] Easterly, W. and Levine, R. (1997) Africa’s Growth Tragedy: Policies and Ethnic Divisions. The Quarterly Journal of Economics, 112, 1203-1250. http://dx.doi.org/10.1162/003355300555466

[10] Boulding, K.E. (1937) A Note on the Theory of the Black Market. Canadian Journal of Economics and Political Science, 13, 115-118.

[11] Plumptre, A.F.W. (1947) The Theory of the Black Market: Further Considerations. Canadian Journal of Economics and Political Science, 13, 280-282. http://dx.doi.org/10.2307/137456

[12] Michaely, M. (1954) A Geometric Analysis of Black Market Behavior. American Economic Review, 44, 627-637.

[13] Flood, R.P. (1978) Exchange Rate Expectations in Dual Exchange Markets. Journal of International Economics, 8, 6577. http://dx.doi.org/10.1016/0022-1996(78)90039-9

[14] Dornbusch, R. (1986) Special Exchange Rate for Capital Account Transactions. World Bank Economic Review, 1, 3-33. http://dx.doi.org/10.1093/wber/1.1.3

[15] Flood, R.P. and Marion, N. (1983) Exchange Rate Regimes in Transition: Italy 1974. Journal of International Money and Finance, 2, 279-294.

[16] Nkurunziza, J.D. (2002) Exchange Rate Policy and the Parallel Market for Foreign Currency in Burundi. AERC Research Paper 123, African Economic Research Consortium, Nairobi.

[17] Lizondo, J.S. (1987) Exchange Rate Unification and Balance of Payments under Dual Exchange Markets. Journal of Development Economics, 26, 37-53. http://dx.doi.org/10.1016/0304-3878(87)90050-2

[18] Marion, N. (1994) Dual Exchange Rates in Europe and Latin America. World Bank Economic Review, 8, $213-245$. http://dx.doi.org/10.1093/wber/8.2.213

[19] Pinto, B. (1991) Black market Premia, Exchange Rate Unification and Inflation in Sub-Saharan Africa. World Bank Economic Review, 3, 321-338. 
Scientific Research Publishing (SCIRP) is one of the largest Open Access journal publishers. It is currently publishing more than 200 open access, online, peer-reviewed journals covering a wide range of academic disciplines. SCIRP serves the worldwide academic communities and contributes to the progress and application of science with its publication.

Other selected journals from SCIRP are listed as below. Submit your manuscript to us via either submit@scirp.org or Online Submission Portal.
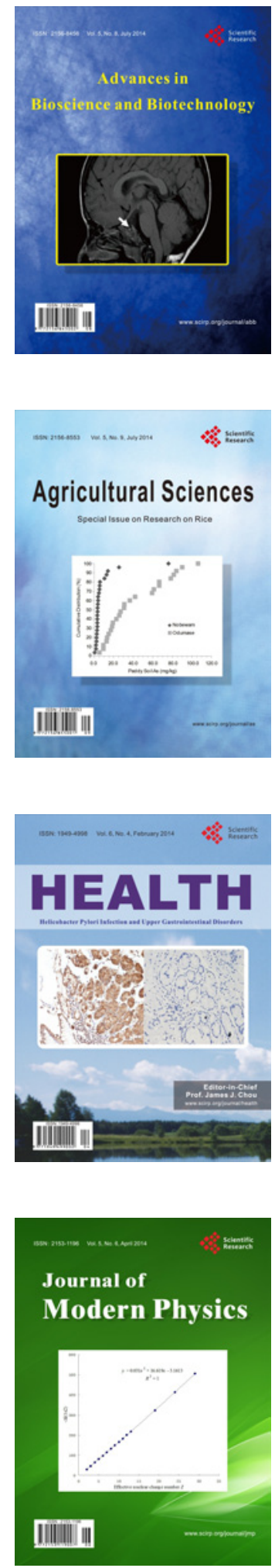
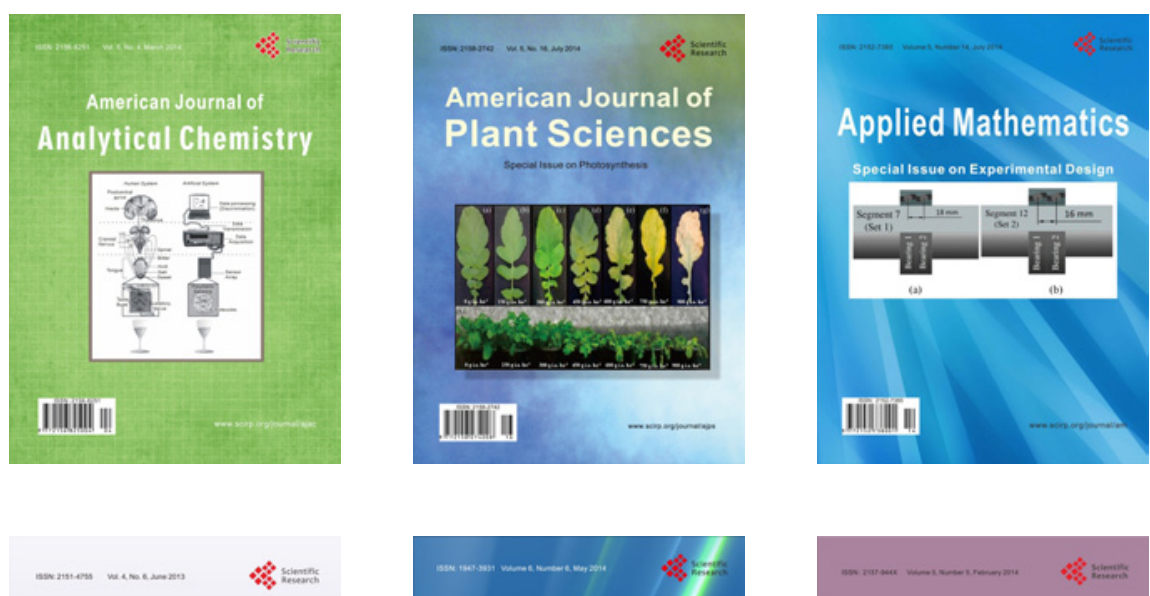

Creative Education
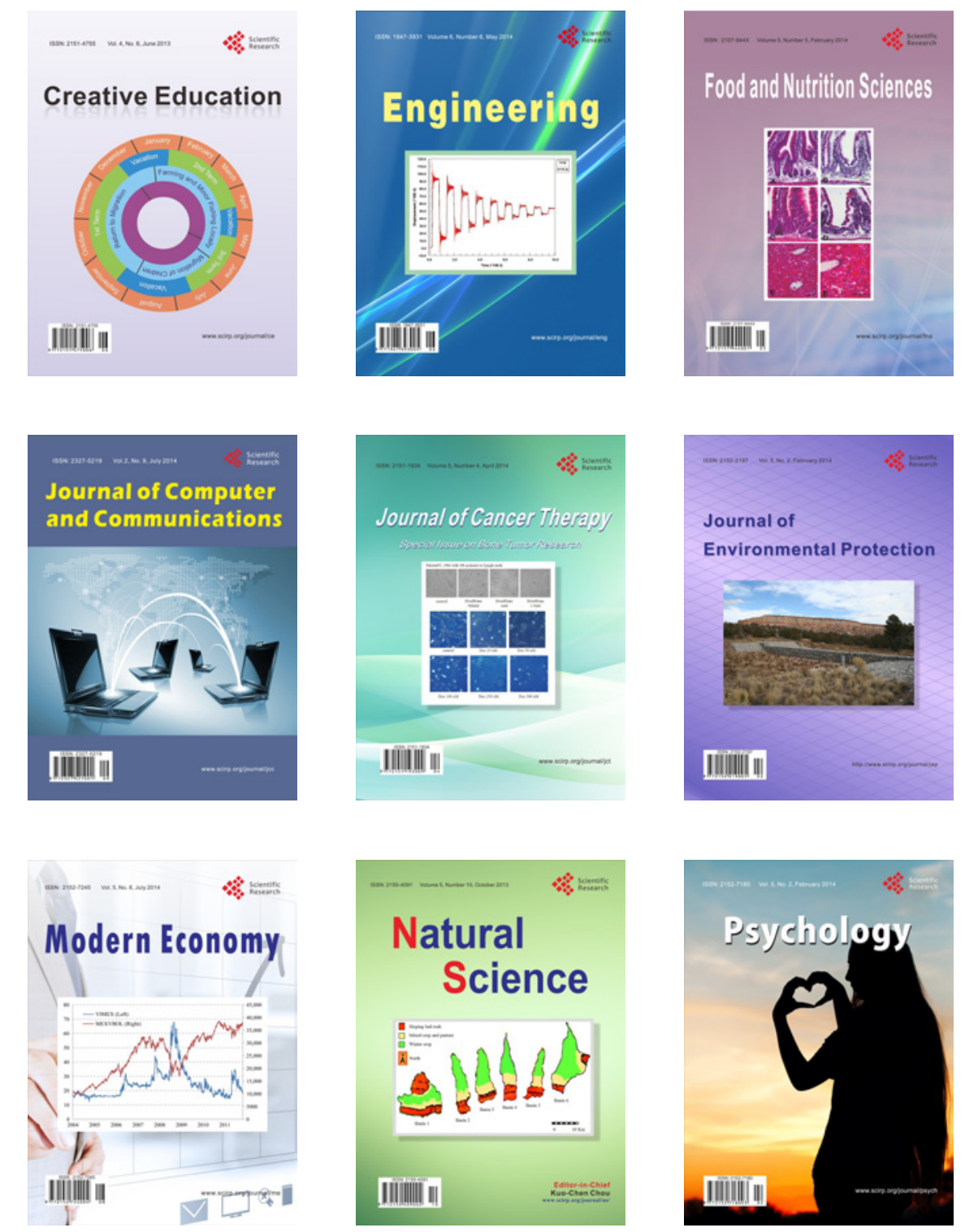